AGRICA: Journal of Sustainable Dryland Agriculture, 13 (2): 136-147 (2020)

ISSN-Online: 2715-4955; ISSN-Cetak: 2715-6613

DOI: https://doi.org/10.37478/agr.v13i2.734

\title{
PEMANFAATAN LIMBAH CUCIAN BERAS HITAM SEBAGAI PUPUK ORGANIK CAIR TERHADAP TANAMAN SAWI HIJAU (Brassica juncea L.)
}

\author{
Murdaningsih, Josina I. B. Hutubessy dan Albertus M. T. Hurint \\ Program Studi Agroteknologi, Fakultas Pertanian Universitas Flores \\ Jln. Sam Ratulangi XX Paupire, Kabupaten Ende, Nusa Tenggara Timur \\ murdaningsih11@gmail.com
}

\begin{abstract}
Utilization of Black Rice Waste as Liquid Organic Fertilizer on Green Plants (Brassica juncea $\mathbf{L}$ ). This study aims to determine the application dose of liquid organic fertilizer from black rice waste water on the growth and yield of mustard greens. The research was carried out at the Experimental Garden of the Faculty of Agriculture, University of Flores for 6 months from June to November. The research was carried out using a randomized block design consisting of 6 doses of black rice liquid waste (Liquid Organic Fertilizer: LOF), namely: P0 = without LOF, P1 = 2,400 ltr $/ \mathrm{ha}=750 \mathrm{ml} / \mathrm{plot}$; P2: $4800 \mathrm{ltr} / \mathrm{ha}=1500 \mathrm{ml} / \mathrm{plot} ; \mathrm{P} 3: 7200 \mathrm{ltr} / \mathrm{ha}=2250 \mathrm{ml} / \mathrm{plot} ; \mathrm{P} 4: 9600 \mathrm{ltr} / \mathrm{ha}=3000$ $\mathrm{ml} / \mathrm{plot}$; P5: $1200 \mathrm{ltr} / \mathrm{ha}=3750 \mathrm{ml} / \mathrm{plot}$; which was repeated 4 times, so there were 24 experimental experiments. The application of liquid organic fertilizer from black rice liquid waste to mustard greens showed an average response to an increase in plant height of $5.08 \%$, leaf number of $7.95 \%$ and leaf area of $17.59 \%$. The yield uptake variable was $11.51 \%$, and the application dose of $9600 \mathrm{ltr} / \mathrm{ha}$ gave a plant height of $46.41 \mathrm{~cm}$, number of leaves 8.25 , leaf area $1691.35 \mathrm{~cm}^{2}$, and fresh weight of mustard greens $\tan ^{-1}$ of 153.65 and the weight of mustard ha- ${ }^{-1}$ was 24.58 tonnes, but not significantly different from P3 (7200 ltr/ha).
\end{abstract}

Keywords: Liquid organic fertilizer, Mustard greens, Rice washing water, Waste.

\section{PENDAHULUAN}

Limbah air cucian beras atau lebih dikenal dengan istilah Leri oleh masyarakat, biasanya hanya dibuang sebagai limbah dan tidak mempunyai nilai ekonomis. Padahal dalam limbah air cucian beras masih mengandung karbohidrat jenis pati sebanyak 85-90\% yang dapat terbuang bersama air pada saat proses pencucian beras (Suratmiyati et al., 2016). Air cucian beras memiliki banyak manfaat bagi tanaman, mudah diperoleh petani dan ramah lingkungan, air limbah cucian beras merupakan produk limbah yang berasal dari proses produksi rumah tangga yang tidak memiliki nilai ekonomis (Bahar, 2016). Sehingga dapat dikatagorikan bahwa air cucian beras adalah salah satu limbah rumah tangga yang dapat dimanfaatkan sebagai pupuk cair untuk memenuhi 
Murdaningsih: Pemanfaatan limbah cucian beras hitam sebagai pupuk organik cair

kebutuhan unsur hara tanaman (Himayana dan Aini, 2018).

Air cucian beras merupakan sumber primer bahan organik bagi jaringan tanaman (Purnawati et al., 2016). Limbah air cucian beras mengandung senyawa organik yang dapat dimanfaatkan sebagai sumber hara. jadi air cucian beras berpotensi sebagai pengganti pupuk kimia untuk meningkatkan pertumbuhan tanaman (Wardiah dan Linda, 2014). Unsur N, P, $\mathrm{K}$ dapat diperoleh dari pemberian pupuk organik, salah satunya berasal dari limbah air cucian beras. Air cucian beras banyak mengandung unsur yang bermanfaat bagi pertumbuhan diantaranya unsur $\mathrm{N}, \mathrm{P}, \mathrm{K}, \mathrm{Mg}$ dan karbohidrat (Zistalia et al., 2018). Penyiraman air cucian beras dengan konsentrasi yang berbeda berpengaruh terhadap pertumbuhan tanaman pacar air dan konsentrasi air cucian beras yang memberikan berat kering yang paling besar adalah konsentrasi 100\% (Wayan et al., 2014)

Sayuran sawi merupakan sayuran yang mengandung nutrisi dan bermanfaat bagi tubuh manusia serta dapat tumbuh baik pada dataran rendah maupun dataran tinggi. Upaya peningkatan produksi, dalam usaha tani secara agronomis untuk meningkatkan hasil tanaman sawi adalah dengan pemberian nutrisi berupa unsur hara seperti pupuk organik cair yang mudah dalam aplikasinya. Produksi sawi di Kabupaten Ende dengan luas 1.486 ha dengan produktivitas 4,29 ton/ha masih rendah dibandingkan dengan produksi sawi Nasional sebesar 10,42 ton/ha. (BPS, 2018). Kondisi ini salah satunya disebabkan adanya pemupukan yang belum optimal.

Sayuran sawi pakcoy (Brassica rapa L.) yang bebas residu pestisida, sehingga aman bagi konsumen maka perlu dilakukan budidaya secara organik. Salah satu bahan organik yang dapat mempercepat proses penyuburan tanah adalah pupuk organik cair dan MOL (Mikroorganisme Lokal) keong emas (Yuliani, 2015). Produktivitas tanaman sawi dengan penambahan bahan organik dan unsur hara dari pupuk organik cair yang dibuat dari limbah sayuran dapat meningkatkan pertumbuhan dan hasil tanaman sawi dengan dosis masingmasing $500 \mathrm{~mL}$ menghasilkan jumlah daun, luas daun, bobot segar dan bobot kering sawi tertinggi (Pardosi et al., 2014).

Beberapa penelitian telah dilakukan, diantaranya penggunaan 
pupuk organik limbah sayur rumah tangga pada tanaman pakcoy mempunyai pengaruh sangat nyata pada setiap peningkatan dosis terhadap peningkatan prosentase tinggi tanaman $(15,50 \%)$, jumlah daun $(12,58 \%)$, luas daun $(21,88 \%)$, berat segar per tanaman $(12,93 \%)$, dan berat pakcoy per ha $(12,91 \%)$. Penggunaan pupuk organik limbah sayur rumah tangga pada tanaman pakcoy sebanyak 20 ton/ha menunjukkan tinggi tanaman $26,38 \mathrm{~cm}$, jumlah daun per tanaman 12 helai, luas daun per tanaman $371,22 \mathrm{~cm}^{2}$, berat segar pakcoy per tanaman 84,79 gram, dan berat pakcoy per ha 16.96 ton/ha (Murdaningsih dan Darman, 2018)

Aplikasi POC dari limbah pasar pada tanaman sawi juga berpengaruh nyata terhadap tinggi tanaman, jumlah daun, bobot segar tanaman sawi, bobot segar sawi per ha dan dosis 40 liter/ha menunjukkan pertumbuhan tinggi tanaman 24,68 cm, jumlah daun 9,25 helai, bobot segar sawi 147,40 gr dan produksi sawi 23,58 ton/ha (Murdaningsih, 2020)

Pemberian air cucian beras dengan konsentrasi $100 \%$ dan interval penyiraman 3 hari sekali pada bibit kelapa sawit berpengaruh baik terhadap pertumbuhan lilit batang dan jumlah daun (Zistalia et al., 2018). Penelitian juga dilakukan pada tanaman kankung, bahwa Pemberian air beras dapat meningkatkan pertumbuhan tanaman pada konsentrasi 1,5 liter air beras yang dibuktikan dari bobot tanaman segar per tanaman dan bobot segar/plot dan bobot kering tanaman (Bahar, 2016).

Penggunaan pupuk kimia yang berlebihan dan terus menerus menyebabkan ketidakseimbangan unsur hara dan struktur tanah, berefek pada lahan pertanian. Penggunaan pupuk organik bisa menjadi solusinya. pemberian inokulan pada air limbah beras tidak signifikan untuk semua perlakuan. Akan tetapi hasil inokulan II + pupuk anorganik 25\% cenderung lebih baik dan menguntungkan dibanding yang lain (Puspitasari et al., 2015).

Penggunaan air cucian beras secara umum dengan berbagai konsentrasi pada tanaman pakcoy, dimana $100 \%$ air cucian beras menunjukkan pertumbuhan terbaik untuk semua parameter, jadi air cucian beras berpotensi sebagai pengganti pupuk kimia untuk meningkatkan pertumbuhan pakchoy (Wardiah dan Linda, 2014). Demikian juga Perlakuan $100 \%$ konsentrasi air cucian beras menghasilkan diameter tangkai tanaman semua umur 
Murdaningsih: Pemanfaatan limbah cucian beras hitam sebagai pupuk organik cair

pengamatan, bobot segar total tanaman

dan bobot kering tanaman umur pengamatan 18 dan 30 hst yang lebih tinggi dibandingkan dengan konsentrasi yang lebih rendah. Pada peubah pengamatan bobot segar total tanaman, bobot segar akar tanaman umur 18, 24 dan 30 hst dan bobot kering total tanaman umur pengamatan 24 hst, namun perlakuan konsentrasi $100 \%$ air cucian beras menunjukkan hasil yang sama dengan konsentrasi $75 \%$ (Himayana dan Aini, 2018). Jenis beras yang berbeda akan memiliki kandungan nutrisi yang berbeda pula, dengan demikian penggunaan limbah air cucian beras hitam memiliki kandungan yang berbeda, yang tentunya juga memiliki potensi digunakan sebagai bahan pembuatan pupuk organic cair.

Penelitian ini tentunya sesuai dengan konsep sistem pertanian berkelanjutan dengan "zero waste" dan ramah lingkungan, sehingga tujuan yang ingin diketahui adalah dosis aplikasi pupuk organik cair dari limbah air cucian beras hitam terhadap pertumbuhan dan hasil tanaman sawi.

\section{BAHAN DAN METODE}

\section{Tempat dan Waktu}

Penelitian dilaksanakan di kebun percobaan, Fakultas Pertanian
Universitas Flores, Kelurahan

Lokoboko, Kecamatan Ndona, Kabupaten Ende. Pada bulan Juni sampai bulan November 2019.

\section{Bahan dan Alat}

Bahan yang digunakan adalah benih sawi hijau, pupuk kandang sapi, limbah air cucian beras, daun pisang,air kelapa, dan alat yang digunakan adalah cangkul,skop, timbangan analitik, mistar,meter, kamera, parang, gembor, alat tulis dan tali rafia.

\section{Prosedur Penelitian}

Penelitian dilakukan dengan rancangan acak kelompok (RAK) yang terdiri dari 6 perlakuan dosis POC limbah air cucian beras hitam yaitu: $\mathrm{P} 0=$ Tanpa POC, P1 = 2400 ltr $/ \mathrm{ha}=750$ $\mathrm{ml} /$ petak; P2 $=4800$ ltr $/$ ha $=1500$ $\mathrm{ml} /$ petak; P3 $=7200 \mathrm{ltr} / \mathrm{ha}=2250$ $\mathrm{ml} /$ petak; P4 $=9600 \mathrm{ltr} / \mathrm{ha}=3000$ $\mathrm{ml} /$ petak; P5 $=1200 \mathrm{ltr} / \mathrm{ha}=3750$ $\mathrm{ml} /$ petak, yang diulang 4 kali sehingga terdapat 24 petak percobaan

\section{Pembuatan Pupuk Organik Cair (POC)}

Bahan pembuatan pupuk organik cair adalah beras hitam $10 \mathrm{~kg}$ lalu dicuci sehingga didapatkan air cucian beras hitam sebanyak 35 ltr dan Air kelapa yang sudah tua sebanyak 5 ltr dimasukan ke dalam wadah lalu diaduk hingga 
merata dan ditutup rapat hingga udara tidak dapat masuk. Pengadukan setiap hari selama 14 hari, yang disimpan di tempat teduh dan terhindar dari sinar matahari langsung (Rahman, 2015).

\section{Pengolahan Lahan dan Aplikasi POC}

Pengolahan tanah dilakukan dengan menggemburkan tanah lalu dibuat bedengan dengan ukuran 1,25 $\mathrm{x}$ 2,5 m. Kemudian ditambahkan pupuk kandang sapi dengan dosis 5 ton/ha atau $3,75 \mathrm{~kg}$ (Ely et al., 2014). Benih sawi disemaikan selama dua minggu, setelah itu bibit tanaman dipindahkan kebedengan dengan jarak tanam $25 \times 25$ $\mathrm{cm}$.

Pupuk organik cair limbah air cucian beras hitam diaplikasikan sebanyak 3 kali pada umur 7; 14 dan 21 hst dengan dosis setiap perlakuan di bagi tiga kemudian dicampurkan dengan air 10 liter air bersih, cara pemberian dengan menyiram pada setiap bedengan perlakuan yang bebeda pada setiap perlakuan (P1) dengan dosis 250 $\mathrm{ml} /$ petak, perlakuan kedua (P2) dengan dosis $500 \mathrm{ml} /$ petak, perlakuan ketiga (P3) dengan dosis $750 \mathrm{ml} /$ petak, dan (P4) dengan dosis $1000 \mathrm{ml} /$ petak, (P5) dengan dosis $1250 \mathrm{ml} /$ petak.

Pemeliharaan tanaman meliputi Penyiraman yang dilakukan secukupnya sesuai dengan kondisi lapang dengan menggunakan gembor. Penyulaman pada awal pertumbuhan tanaman serta penyiangan dan penggemburan tanah, sedangkan pemanenan dilakukan pada saat tanaman berumur 30 hari setelah tanam dengan cara mencabut tanaman, membuang akar dan daun-daunan yang sudah tua

\section{Variabel Pengamatan}

Variabel Pertumbuhan yang diamati pada umur 10, 15, 20, dan 25 hst yaitu tinggi tanaman yang diukur mulai dari permukaan tanah sampai daun tertinggi, variable jumlah daun dengan cara menghitung dan variable luas daun $\left(\mathrm{cm}^{2}\right)$ dihitung dengan menggunakan metode panjang $\mathrm{x}$ lebar $\mathrm{x}$ konstanta (0,70) menurut Melky (2013). Sedangkan variabel hasil yang diamati adalah berat segar sawi per tanaman (gr) dengan menimbang semua bagian tanaman sampel (tanpa akar dan daun tua), yang telah dibersihkan kemudian dirata-ratakan, berat segar sawi per ha (ton) dengan mengkonversikan berat per tanaman dengan rumus: berat segar per tanaman $\times$ populasi tanaman per hektar (160.000). Data yang telah diperoleh dianalisis dengan sidik ragam, apabila perlakuan menunjukan pengaruh nyata terhadap variabel yang diamati, maka 
Murdaningsih: Pemanfaatan limbah cucian beras hitam sebagai pupuk organik cair

dilanjutkan dengan uji beda nyata terkecil (BNT) taraf $5 \%$.

\section{HASIL DAN PEMBAHASAN}

Berdasarkan hasil analisis yang telah dilakukan menunjukkan bahwa penggunaan limbah cucian beras hitam sebagai pupuk organik cair dapat memberi pengaruh yang sangat nyata terhadap pertumbuhan tinggi tanaman, jumlah daun, dan luas daun pada semua umur pengamatan yang disajikan pada Tabel 1 berikut ini.

Tabel 1. Pengaruh penggunaan limbah cucian beras hitam sebagai pupuk organik terhadap tinggi tanam $(\mathrm{cm})$, jumlah daun (helai) dan luas daun $\left(\mathrm{cm}^{2}\right)$ pada tanaman sawi hijau

\begin{tabular}{|c|c|c|c|c|c|c|}
\hline \multirow{2}{*}{ Variabel } & \multirow{2}{*}{ Perlakuan } & \multicolumn{4}{|c|}{ Waktu Pengamatan (HST) } & \multirow{2}{*}{ Rata-rata } \\
\hline & & 10 & 15 & 20 & 25 & \\
\hline \multirow{6}{*}{$\begin{array}{l}\text { Tinggi } \\
\text { tanaman } \\
(\mathrm{cm})\end{array}$} & P0 & $12,98 \mathrm{a}$ & $21,47 \mathrm{a}$ & $31,58 \mathrm{a}$ & $39,97 \mathrm{a}$ & 26,50 \\
\hline & $\mathrm{P} 1$ & 13,92 a & 22,01 a & $32,92 \mathrm{ab}$ & $40,87 \mathrm{ab}$ & 27,44 \\
\hline & $\mathrm{P} 2$ & $15,03 \mathrm{bc}$ & $22,94 \mathrm{ab}$ & $35,33 \mathrm{c}$ & $43,43 \mathrm{c}$ & 29,18 \\
\hline & P3 & $15,95 \mathrm{c}$ & $23,92 \mathrm{bc}$ & $35,41 \mathrm{c}$ & $44,67 \mathrm{~cd}$ & 29,99 \\
\hline & $\mathrm{P} 4$ & $16,40 \mathrm{c}$ & $24,99 \mathrm{c}$ & $38,01 \mathrm{~d}$ & $46,41 \mathrm{~d}$ & 31,45 \\
\hline & P5 & $14,25 \mathrm{ab}$ & $22,27 \mathrm{a}$ & $34,17 \mathrm{bc}$ & $44,19 \mathrm{c}$ & 28,72 \\
\hline BNT 5\% & & 1,61 & 1,75 & 1,63 & 1,87 & \\
\hline \multirow{6}{*}{$\begin{array}{l}\text { Jumlah } \\
\text { daun } \\
\text { (helai) }\end{array}$} & P0 & $3,55 \mathrm{a}$ & 4,15 a & $5,20 \mathrm{a}$ & $6,65 \mathrm{a}$ & 4,89 \\
\hline & $\mathrm{P} 1$ & $3,60 \mathrm{a}$ & 4,25 a & $5,40 \mathrm{ab}$ & $6,80 \mathrm{a}$ & 5,01 \\
\hline & $\mathrm{P} 2$ & $3,95 \mathrm{ab}$ & 4,45 a & $6,10 \mathrm{bc}$ & $7,05 \mathrm{ab}$ & 5,39 \\
\hline & P3 & $4.20 \mathrm{bc}$ & $5,00 \mathrm{bc}$ & $6,20 \mathrm{~cd}$ & $7,60 \mathrm{bc}$ & 5,78 \\
\hline & P4 & $4,70 \mathrm{c}$ & $5,40 \mathrm{c}$ & $7,30 \mathrm{~d}$ & $8,25 \mathrm{~d}$ & 6,41 \\
\hline & $\mathrm{P} 5$ & $3,75 \mathrm{a}$ & $4,60 \mathrm{ab}$ & $6,15 \mathrm{c}$ & $7,70 \mathrm{~cd}$ & 5,53 \\
\hline BNT 5\% & & 0,58 & 0,41 & $\mathbf{0 , 7 3}$ & $\mathbf{0 , 5 7}$ & \\
\hline \multirow{6}{*}{$\begin{array}{l}\text { Luas } \\
\text { daun } \\
\left(\mathrm{cm}^{2}\right)\end{array}$} & P0 & $74,98 \mathrm{a}$ & $128,32 \mathrm{a}$ & $607,20 \mathrm{a}$ & $908,61 \mathrm{a}$ & 429,78 \\
\hline & $\mathrm{P} 1$ & $78,91 \mathrm{a}$ & $285,69 \mathrm{~b}$ & $711,98 \mathrm{~b}$ & $979,04 \mathrm{ab}$ & 513,91 \\
\hline & $\mathrm{P} 2$ & $83,11 \mathrm{ab}$ & $307,50 \mathrm{bc}$ & $754,93 \mathrm{~b}$ & $1120,62 \mathrm{c}$ & 566,54 \\
\hline & P3 & $110,31 \mathrm{c}$ & $361,39 \mathrm{~cd}$ & $853,00 \mathrm{~d}$ & $1204,84 \mathrm{de}$ & 632,38 \\
\hline & $\mathrm{P} 4$ & $114,75 \mathrm{c}$ & $388,39 \mathrm{~d}$ & $1076,65 \mathrm{e}$ & $1691,35 \mathrm{f}$ & 817,79 \\
\hline & P5 & $82,53 \mathrm{a}$ & $286,32 \mathrm{~b}$ & $759,95 \mathrm{c}$ & $1186,54 \mathrm{~cd}$ & 578,84 \\
\hline BNT 5\% & & 22,71 & 57,56 & 68,11 & 78,52 & \\
\hline
\end{tabular}

Keterangan: Angka yang diikuti oleh huruf yang sama pada kolom yang sama menunjukkan tidak berbeda nyata pada taraf 5\% uji BNT.

Dari ke enam perlakuan yang dicobakan dan berdasarkan hasil analisis statistik diketahui bahwa penggunaan pupuk organik cair (POC) limbah cucian beras hitam berpengaruh sangat nyata pada variabel pertumbuhan (tinggi tanam jumlah daun dan luas daun) pada pengamatan umur tanaman $10 \mathrm{hst}, 15$ hst, 20 hst dan 25 hst. Perlakuan pemberian pupuk organik cair (POC) 
limbah cucian beras hitam 9600 ltr/ha (P4) merupakan perlakuan yang optimal bagi pertumbuhan tanaman yaitu tinggi tanaman jumlah daun dan luas daun, tetapi tidak berbeda nyata dengan (P3) 7200 ltr/ha dimana pemberian pupuk organik cair (POC) limbah cucian beras hitam dapat menabah unsur hara bagi tanaman sebesar nitrogen (N) 0,014\% yang berfungsi untuk pembentukan daun (klorofil) juga berperan penting dalam pembentukan karbonhidrat, kandungan fosfor (P) 14,452\% yang berperan untuk memacu pertumbuhan akar dan pembentukan sistem perakaran yang baik dari benih tanaman muda, kalium(K) 0,02\% (Rahman, 2015). Sementara dosis dari kotoran sapi untuk pertumbuhan akar dan pembentukan system perakaran mempunyai kadar $\mathrm{N}$ 1,03\%; P 0,23\%; K 1,3\%.

Dengan demikian pemberian dosis 9600 ltr/ha air cucian beras setara dengan N 1,334 ltr/ha, P 1387,2 ltr/ha, K 1,92 ltr/ha dan jika dosis 7200 ltr/ha maka setara N 1,008 ltr/ha, P 1040,4 ltr/ha, K 1,44 ltr/ha. Dengan demikian juga dalam penelitian digunakan pupuk dasar kotoran sapi dengan takaran dosis 5 ton/ha yang setara dengan $\mathrm{N}$ 51,5 $\mathrm{kg} / \mathrm{ha}, \mathrm{P} 11,5 \mathrm{~kg} / \mathrm{ha}, \mathrm{K} 65 \mathrm{~kg} / \mathrm{ha}$, jadi total $\mathrm{N}, \mathrm{P}, \mathrm{K}$ yang bisa digunakan tanaman sawi dalam penelitian pada dosis 9600 ltr/ha adalah N 52,84 kg/ha; P 1398,7 kg/ha dan K 66,92 kg/ha. Hal tersebut disebabkan karena pemberian pupuk organik cair (POC) limbah cucian beras hitam dapat menjaga dan menambah unsur hara dalam tanah. Pemanfaatan pupuk organik cair (POC) limbah cucian beras hitam merupakan alternatif yang potensial karena pupuk organik cair (POC) limbah cucian beras hitam mudah didapat dan tidak dapat mengeluarkan biaya yang banyak. Pemberian pupuk organik cair (POC) mencukupi kebutuhan hara tanaman sehingga dapat mendukung proses metabolisme tanaman dan memberikan pengaruh yang baik terhadap pertumbuhan tanaman.

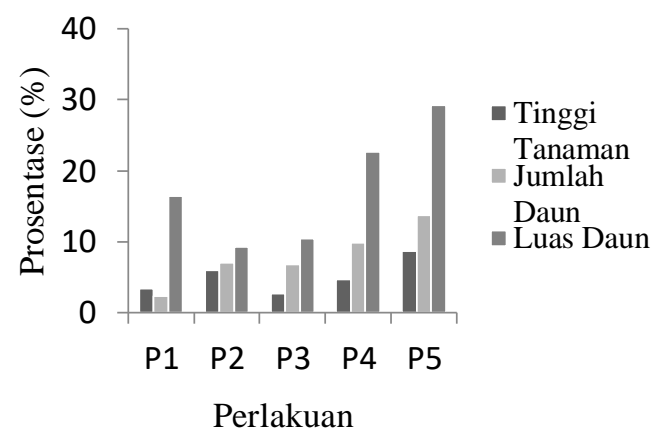

Gambar 1. Prosentase peningkatan penggunaan POC Limbah air cucian beras hitam dibandingkan tanpa POC terhadap tinggi tanaman, jumlah daun dan luas daun tanaman sawi 
Murdaningsih: Pemanfaatan limbah cucian beras hitam sebagai pupuk organik cair

Pengaruh pemberian POC limbah air cucian beras terhadap variable pertumbuhan tanaman sawi mempunyai pengaruh terhadap prosentase peningkatan tinggi tanaman, jumlah daun dan luas daun, seperti terlihat pada Gambar 1, sehingga diperoleh peningkatan rata-rata tinggi tanaman $5,08 \%$, rata-rata peningkatan jumlah daun $7,95 \%$ dan rata-rata peningkatan luas daun 17,59\%. Hasil penelitian sebelumnya juga menyatakan bahwa dosis pupuk organik cair daun gamal memberikan pengaruh yang nyata terhadap tinggi tanaman $(8,332)$, jumlah daun $(7,911)$ dan berat segar $(7,027)$ (Triadiawarman dan Rudi, 2019). Demikian juga pemberian pupuk organik cair dapat meningkatkan tinggi tanaman, jumlah daun, berat basah dan berat kering tanaman sawi. Perlakuan dengan pupuk organik cair $40 \%$ menunjukkan tinggi tanaman tertinggi, jumlah daun paling banyak serta berat basah dan berat kering yang paling berat, masingmasing 154,93 gr dan 44,1 gr (Moi, 2015)

Nilai prosentase dari setiap perlakuan P0 sampai P4 mengalami peningkatan sedangkan pada perlakuan P5 peningkatannya lebih kecil atau lebih rendah untuk mendukung pertumbuhan.
Tanaman harus tercukupi jumlah haranya, namun jika berlebihan kemungkinan tidak dapat terserap oleh tanaman. Jadi penurunan nilai prosentase pada P5 dianggap bawah unsur hara yang terdapat pada perlakuan tersebut sudah berlebihan.

Dilihat dari persentase peningkatan bahwa pada perlakuan tanpa dosis pupuk organik cair (POC) limbah cucian beras hitam, memberi pengaruh yang paling rendah dibandingakan dengan perlakuan lain. Hal ini disebabkan karena perlakuan tanpa pemberian POC limbah cucian beras hitam diduga bahan organik yang ada dalam tanah sudah berkurang, sehingga dapat memperlambatkan pertumbuhan sawi hijau. Dengan demikian pengaruh penggunaan (POC) limbah cucian beras hitam dapat meningkatkan pertumbuhan tanaman sawi hijau terhadap variabel pengamatan tinggi tanaman, jumlah daun, dan luas daun mempunyai rata-rata peningkatan setiap tingkatannya masing-masing sebesar 5,08\% tinggi tanaman, 13,73\% jumlah daun dan $17,59 \%$ luas daun.

Hal tersebut sesuai hasil penelitian sebelumnya bahwa perlakuan pupuk organik cair (POC) air beras perlakuan $20 \mathrm{ml} / \mathrm{ltr}$ per tanam atau setara dengan 160.000 tanam $\times 20 \mathrm{ml} / \tan =3,200.000$ 
$\mathrm{ml} / \mathrm{ha}$ atau $3.200 \mathrm{ltr} / \mathrm{ha}$. Menunjukkan jumlah daun yang terbanyak dengan rata-rata jumlah daun 16,22 helai dan tinggi tanam $33,18 \mathrm{~cm}$. Juga didukung oleh, Bahar (2016) bahwa limbah air cucian beras terhadap pertumbuhan tanaman kangkung darat (Ipomoea reptans poir) sebanyak 1,5 ltr/petak dengan ukuran petak $150 \mathrm{~cm}$ x $100 \mathrm{~cm}$ mempunyai pengaruh terhadap tinggi tanam sebesar $7,40 \mathrm{~cm}$, jumlah daun sebanyak 5,73 helai, panjang daun sebesar $4.27 \mathrm{~cm}$. Sedangkan bobot segar tanaman kangkung sebanyak 1.00 gr, berat segar per plot sebesar 7,83 $\mathrm{kg}$ dan dan bobot kering tanaman sebesar 0.21 gr.

Berdasarkan hasil analisis statistik menunjukkan bahwa penggunaan limbah cucian beras hitam sebagai pupuk organik dapat memberi pengaruh yang sangat nyata terhadap variabel hasil yang meliputi berat segar sawi per tanaman, dan berat segar sawi per hektar yang disajikan pada Tabel 2 berikut.

Tabel 2. Pengaruh penggunaan limbah cucian beras hitam sebagai pupuk organik terhadap berat segar sawi per tanaman (gr) dan berat segar sawi per ha (ton)

\begin{tabular}{ccc}
\hline Perlakuan & $\begin{array}{c}\text { Berat Segar Sawi } \\
\text { per tanaman }(\mathbf{g})\end{array}$ & $\begin{array}{c}\text { Berat Segar Sawi } \\
\text { Per Ha (ton) }\end{array}$ \\
\hline P0 & $92,85 \mathrm{a}$ & $14,86 \mathrm{a}$ \\
P1 & $97,05 \mathrm{ab}$ & $15,53 \mathrm{ab}$ \\
P2 & $126,20 \mathrm{c}$ & $20,19 \mathrm{c}$ \\
P3 & $137,05 \mathrm{~cd}$ & $21,93 \mathrm{~cd}$ \\
P4 & $153,65 \mathrm{~d}$ & $24,58 \mathrm{~d}$ \\
P5 & $127,45 \mathrm{c}$ & $20,39 \mathrm{c}$ \\
\hline BNT 5\% & $\mathbf{2 5 , 4 5}$ & $\mathbf{4 , 0 7}$ \\
\hline
\end{tabular}

Keterangan: Angka yang diikuti oleh huruf yang sama pada kolom yang samamenunjukkan tidak berbeda nyata pada taraf 5\% uji BNT.

Berdasarkan hasil analisis stastik bahwa penggunaan pupuk organik cair (POC) limbah cucian beras hitam yang diaplikasi pada tanaman sawi dapat memberikan pengaruh yang sangat nyata terhadap variable hasil yang meliputi berat segar sawi per tanaman (gr) dan berat segar sawi per ha (ton).

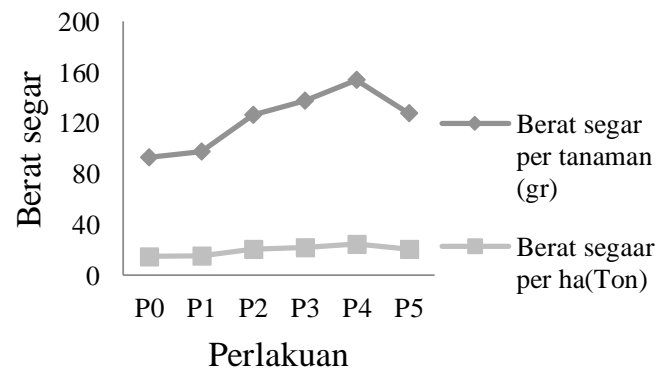

Gambar 2. Pengaruh POC Limbah air cucian beras hitam pada Produksi Sawi Hijau 
Murdaningsih: Pemanfaatan limbah cucian beras hitam sebagai pupuk organik cair

Pada Gambar 2 hasil analisis sidik ragam menunjukkan bahwa perlakuan P4 merupakan perlakuan terbaik dan tidak berbeda nyata dengan perlakuan P3, dan pada gambar 2 juga menunjukkan bahwa perlakuan P4 terbaik dan setelah dosis ditingkatkan lagi (P5) menunjukkan produksi segar yang menurun. Hal tersebut sesuai dengan kebutuhan hara tanaman, jika diberikan berleihan maka tidak dapat dipergunakan oleh tanaman.

Ada pun peningkatan hasil berat segar sawi per tanaman dari P0 (tanpa POC limbah cucian beras hitam) ke P1 (2400 ltr/ha ) sebesar: 4,33\%, P1 ke P2 (4800 ltr/ha ) sebesar: 23,09\%, P2 ke P3 (7200 ltr/ha) sebesar : 7,92\%, P3 ke P4 (9600 ltr/ha) sebesar: 10,80\%, dan ratarata meningkat $11,51 \%$, sedangkan perlakuan P4 ke P5 (1200 ltr/ha) menurun sebesar: 17,04\%. Dengan demikian penggunaan pupuk organik cair limbah cucian beras hitam memberikan hasil yang optimal untuk peningkatan produksi tanaman sawi. Nilai persentase hasil dari setiap perlakuan P0 samapi P4 mengalami peningkatan sadangkan pada perlakuan P5 meningkat lebih sedikit. Hal ini terjadi karena kelebihan unsur hara bagi tanaman dan tidak dapat dimanfaatkan oleh tanaman.

Melihat nilai prosentase hasil tanaman sawi yang terbaik terdapat pada perlakuan P4 dengan dosis 9600 ltr/ha menunjukkan berat segar sawi per tanaman sebesar 153,65 gr atau 24,58 ton/ha tapi tidak berbeda nyata dengan perlakuan P3 yaitu sebesar 137,05 gr/tan atau 21,93 ton/ha. Terjadinya hal ini karena POC limbah cucian beras hitam dapat menambah unsur hara dalam tanah sehingga dapat menyuburkan tanaman, juga dapat menjaga kesehatan lingkungan. Dengan pemakaian pupuk organik cair (POC) menjadikan tanah lebih gembur dan tidak muda terkikis aliran air. Struktur tanah menjadi lebih kompak dengan adanya penambahan bahan-bahan organik dan lebih tahan menyimpan air di banding dengan tanah yang tidak dipupuk bahan organik. Pada tanah yang miskin bahan organik, air mudah mengalir dengan membawa tanah. Dengan demikian penggunaan pupuk organik cair limbah cucian beras hitam memberikan hasil yang optimal (P4) untuk tanaman sawi, namun tidak berbeda nyata dengan P3.

Hal tersebut di dukung hasil penelitian sebelumnya mengatakan bahwa perlakuan pupuk organik cair 
(POC) air beras perlakuan $20 \mathrm{ml} / \mathrm{ltr}$ per tanam menunjukkan jumlah daun yang terbanyak dengan rata-rata jumlah daun 16,22 helai dan tinggi tanam $33,18 \mathrm{~cm}$. Juga didukung oleh Bahar (2016), bahwa limbah air cucian beras terhadap pertumbuhan tanaman kangkung darat (Ipomoea reptans poir) sebanyak 1,5 ltr/petak mempunyai pengaruh terhadap tinggi tanam sebesar 7,40 cm, jumlah daun sebanyak 5,73 helai, panjang daun sebesar $4.27 \mathrm{~cm}$. Sedangkan bobot segar tanaman kangkung sebanyak 1.00 gr, berat segar per plot sebesar 7,83 $\mathrm{kg}$ dan dan bobot kering tanaman sebesar 0.21 gr.

\section{SIMPULAN}

Penelitian Aplikasi pupuk organik cair dari limbah air cucian beras hitam terhadap tanaman sawi menunjukkan respon rata-rata peningkatan tinggi tanaman $5,08 \%$, jumlah daun $7,95 \%$ dan $17,59 \%$ luas daun. Serta variabel hasil sebesar 11,51\%, dan dosis Aplikasi 9600 ltr/ha memberikan tinggi tanaman $46,41 \mathrm{~cm}$, jumlah daun 8,25 helai, luas daun $1691,35 \mathrm{~cm}^{2}$, serta berat segar sawi per tanaman sebesar 153,65 dan berat sawi per hektar sebesar 24,58 ton, tetapi tidak berbeda nyata dengan P3 (7200 ltr/ha).

\section{UCAPAN TERIMA KASIH}

Tentunya banyak pihak yang membantu dalam kelancaran pelaksanaan Penelitian ini, maka kami menyampaikan ucapan terima kasih yang tidak terhingga kepada pimpinan Universitas Flores, pimpinan Fakultas Pertanian, yang telah memberikan dukungan yang luar biasa. Serta para pengawai kebun dan mahasiswa yang terlibat langsung dalam penelitian ini. Semoga Penelitian ini dapat bermanfaat bagi kemaslahatan masyarakat

\section{DAFTAR PUSTAKA}

Bahar, A. E. Angga. (2016). Pengaruh Pemberian Limbah Air Cucian Beras Terhadap Pertumbuhan Tanaman Kangkung Darat (Ipomoea reptanspoir). Jurnal Mahasiswa Fakultas Pertanian UPP.

Ely, E., Eko, W., dan Suwasono, H. Y. B. (2014). Pengaruh Pupuk Kandang Sapi Pada Pertumbuhan Dan Hasil Tanaman Terong (Solanum melongena) Pada Pola Tanam Tumpangsari Dengan Rumput Gajah (Penisetum purpureum) Tanaman Pertama. Jurnal Produksi Tanaman, 2(7), 533-541.

Himayana, A. T. S., dan Aini, N. (2018). Pengaruh Pemberian Air Limbah Cucian Beras Terhadap Pertumbuhan dan Hasil Tanaman Pakcoy (Brassica rapa var. chinensis). Jurnal Produksi Tanaman. 
Murdaningsih: Pemanfaatan limbah cucian beras hitam sebagai pupuk organik cair

Moi, A. R. (2015). Pengujian Pupuk Organik Cair dari Eceng Gondok (Eichhornia crassipes) Terhadap Pertumbuhan Tanaman Sawi (Brassica juncea). Jurnal MIPA.

Murdaningsih dan Rikardus Darman. (2018). Pemanfaatan Pupuk Organik Limbah Sayur Rumah Tangga Terhadap Pertumbuhan dan Produksi Tanaman Pokcoy ( Brassica rapa L.). Prosiding Forum Komunikasi Perguruan Tinggi Pertanian Indonesia (FKPTPI) 2018 Universitas Syiah Kuala Banda Aceh, 130-136.

Murdaningsih, P. N. S. dan Y. P. (2020). Aplikasi Pupuk Organik Cair dari Limbah Pasar pada Tanaman sawi (Brasica juncea L.). Agrica, 13(1), 57-67.

Pardosi, A. H., Irianto, dan Mukhsin. (2014). Respons Tanaman Sawi terhadap Pupuk Organik Cair Limbah Sayuran pada Lahan Kering. Prosiding Seminar Nasional Lahan Suboptimal.

Purnawati, S., Bagyono, T., dan Fauzie, M. M. (2016). Pemanfaatan Sampah Buah, Air Cucian Beras dan Kotoran Ayam Sebagai Pupuk Organik Cair. Sanitasi: Jurnal Kesehatan Lingkungan, 7(4).

Puspitasari, R. T., Al-widad, S., Suryati, Y., Pradana, N. T., Pertanian, F., dan Muhammadiyah, U. (2015). Pemanfaatan Inokulan Air Limbah Cucian Beras Sebagai Pupuk Organik Pada Tanaman Sedap Malam. Jurnal Matematika, Saint, Dan Teknologi.
Suratmiyati, Mustofa, A., dan Kurniawati, L. (2016). Pemanfaatan Limbah Leri Beras (Hitam, Merah, Putih) Untuk Pembuatan Nata De Leri Dengan Faktor Lama Fermentasi. Jitipari.

Triadiawarman, D., dan Rudi, R. (2019). Pengaruh Dosis dan Interval Waktu Pemberian Pupuk Organik Cair Daun Gamal Terhadap Pertumbuhan dan Hasil Tanaman Sawi (Brassica Juncea L.). Jurnal Pertanian Terpadu.

Wardiah Wardiah dan Linda, H. R. (2014). Potensi Limbah Air Cucian Beras Sebagai Pupuk Organik Cair Pada Pertumbuhan Pakchoy (Brassica rapa L.). Jurnal Biologi Edukasi, 6(1), 34-38.

Wayan, N., Ratnadi, Y., Sumardika, D. I. N., Pd, M., Nyoman, I. G. A., (2014). Pengaruh Penyiraman Air Cucian Beras Dan Pupuk Urea Dengan Konsentrasi Yang Berbeda Terhadap Pertumbuhan Tanaman Pacar Air ( Impatiens balsamina L.). Jurnal Pendidikan Biologi Undiksha, 1(1), 4-5.

Yuliani. (2015). Pemanfaatan MOL (Mikroorganisme Lokal) Keong Emas (Pomoceae canaliculata) dan Pupuk Organik untuk Peningkatan Pertumbuhan dan hasil Tanaman Sawi (Brassica rapa L.). AGROSCIENCE (AGSCI).

Zistalia, R. P., Ariyanti, M., \& Soleh, M. A. (2018). Air Cucian Beras Sebagai Suplemen Bagi Pertumbuhan Bibit Kelapa Sawit. Jurnal hutan pulau-pulau kecil. 